\title{
DAMPAK PERTUMBUHAN PENJUALAN, LEVERAGE, UKURAN PERUSAHAAN,DAN PROFITABILITAS TERHADAP CASH HOLDING
}

\author{
Sufiyati \\ Universitas Tarumanagara \\ sufiyati@fe.untar.ac.id \\ Liana Susanto \\ Universitas Tarumanagara \\ lianas@fe.untar.ac.id \\ Sofia Prima Dewi \\ Universitas Tarumanagara \\ sofiad@fe.untar.ac.id \\ Merry Susanti \\ Universitas Tarumanagara \\ merrys@fe.untar.ac.id
}

\begin{abstract}
This study aims to determine whether sales growth has a negative impact on cash holding, whether leverage has a positive impact on cash holding, whether company size has a positive impact on cash holding, and whether profitability has a positive impact on cash holding. The population is a manufacturing company that is consistently listed on the Indonesia Stock Exchange during 2016-2019. Purposive sampling was used as a sampling technique. The data is processed using EVIEWS. This study shows that sales growth has a negative impact on cash holding, leverage does not have a positive impact on cash holding, firm size does not have a positive impact on cash holding, and profitability does not have a positive impact on cash holding.

Keywords: Cash Holding, Sales Growth, Leverage, Company Size, Liquidity, Profitability
\end{abstract}

\begin{abstract}
ABSTRAK
Penelitian ini bertujuan untuk mengetahui apakah pertumbuhan penjualan berdampak negatif terhadap cash holding, apakah leverage berdampak positif terhadap cash holding, apakah ukuran perusahaan berdampak positif terhadap cash holding, dan apakah profitabilitas berdampak positif terhadap cash holding. Populasi adalah perusahaan manufaktur yang terdaftar secara konsisten di Bursa Efek Indonesia selama tahun 20162019. Purposive sampling digunakan sebagai teknik pengambilan sampel. Data diolah dengan mengggunakan EVIEWS. Penelitian ini menunjukkan hasil bahwa pertumbuhan penjualan berdampak negatif terhadap cash holding, leverage tidak berdampak positif terhadap cash holding, ukuran perusahaan tidak berdampak positif terhadap cash holding, dan profitabilitas tidak berdampak positif terhadap cash holding.

Kata kunci: Cash Holding; Pertumbuhan Penjualan; Leverage; Ukuran Perusahaan; Profitabilitas
\end{abstract}




\section{PENDAHULUAN}

Kas merupakan aset yang sangat penting, paling likuid, dan dapat digunakan langsung dibandingkan dengan aset-aset lainnya. Dengan adanya kas yang cukup, maka perusahaan dapat membiayai kegiatan operasionalnya, membagikan deviden kepada para investor, melakukan investasi, serta melakukan ekspansi. Menurut (Ridha, Wahyuni, \& Sari, 2019) cash holding adalah kas yang tersedia di dalam perusahaan. (Alicia, Putra, Fortuna, Felin, \& Purba, 2020) menyatakan bahwa cash holding menjadi salah satu elemen penting dalam hal manajemen likuiditas dimana hal ini akan dapat memengaruhi kinerja perusahaan, sehingga perusahaan perlu menjaga cash holding. Jumlah kas tersedia merupakan hal yang penting agar tidak mengalami kesulitan dalam menjalankan kegiatan operasi perusahaan. Ketika perusahaan memerlukan dana mendadak atau biaya tidak terduga dimana saldo kas tidak mencukupi maka dilakukan penjualan aset bukan kas. Hal ini akan menimbulkan biaya konversi ke dalam bentuk kas. Menurut (Prasetiono, 2016) hal positif perusahaan menahan kas dalam jumlah besar adalah menghemat biaya konversi ke bentuk kas. Kas yang tersedia dalam jumlah banyak bukan berarti kinerja perusahaan bagus. Kas yang berlebihan (idle fund) menunjukkan perusahaan tidak mampu mengelola kas sehingga menimbulkan opportunity cost dimana tingkat pengembalian rendah. Menahan kas dalam jumlah besar dan dalam jangka waktu lama dapat menghilangkan kesempatan perusahaan untuk memperoleh laba yang optimal. Banyak faktor yang memengaruhi jumlah kas yang tersedia di dalam perusahaan diantaranya pertumbuhan penjualan, leverage, ukuran perusahaan, dan profitabilitas. Pertumbuhan penjualan yang tinggi mencerminkan perusahaan menggunakan kas dalam jumlah besar untuk ekspansi sehingga kas yang ditahan tidak besar. Leverage tinggi menggambarkan pendanaan eksternal yang tinggi sehingga perusahaan harus menyediakan kas untuk pembayaran hutang dan bunga pada saat jatuh tempo. Semakin besar ukuran perusahaan, semakin besar kas yang tersedia untuk mengantisipasi biaya yang tak terduga. Profitabilitas tinggi mencerminkan kemampuan perusahaan menghasilkan laba. Semakin tinggi laba yang dihasilkan semakin tinggi kemampuan perusahaan menghasilkan kas dan menahan kas. Penelitian cash holding dan faktor-faktor yang memengaruhinya sudah banyak dilakukan dan memperoleh hasil yang tidak konsisten. Penelitian ini adalah replikasi penelitian (Alicia, Putra, Fortuna, Felin, \& Purba, 2020) dimana menggunakan tiga variabel independen 
yaitu growth opportunity, leverage, dan firm size. Penelitian ini menambah satu variabel independen lagi yaitu profitabilitas dari penelitian (Margaretha \& Dewi, 2020). Perbedaan lain yaitu penelitian (Alicia, Putra, Fortuna, Felin, \& Purba, 2020) menggunakan sampel perusahaan property dan real estate dengan periode penelitian tahun 20142017, sedangkan penelitian ini

\section{TELAAH LITERATUR}

\section{Pecking Order Theory}

Terkait dengan pecking order theory, (Myers \& Majluf, 1984) menyatakan bahwa perusahaan lebih memilih pembiayaan internal. Kebijakan dividen, fluktuasi laba, serta kesempatan investasi mengakibatkan arus kas yang dihasilkan mungkin lebih besar atau lebih kecil dari pengeluaran investasi. Apabila lebih kecil, langkah pertama perusahaan akan menarik saldo kas atau investasi sekuritasnya. Apabila diperlukan pembiayaan eksternal, akan dikeluarkan terlebih dahulu sekuritas yang paling aman, yaitu dimulai dengan hutang, kemudian mungkin sekuritas hybrid seperti convertible bonds, lalu selanjutnya menerbitkan ekuitas yang merupakan pilihan terakhir. Sejalan dengan hal ini, (Ridha, Wahyuni, \& Sari, 2019)menyatakan bahwa perusahaan dengan tingkat profitabilitas yang tinggi maka akan membiayai sebagian dari investasinya dengan pembiayaan internal, menggunakan sampel perusahaan manufaktur dengan periode penelitian 2017-2019. Tujuan penelitian adalah untuk memperoleh bukti empiris mengenai (1) Dampak negatif pertumbuhan penjualan terhadap cash holding, (2) Dampak positif leverage terhadap cash holding, Dampak positif ukuran perusahaan terhadap cash holding, (4) Dampak positif profitabilitas terhadap cash holding.

dengan demikian rasio kas perusahaan

cenderung tinggi. Menurut Suherman (2017) teori ini menunjukkan kas sebagai penyangga laba ditahan dan kebutuhan investasi. Tujuan memegang kas adalah untuk menghindari pembiayaan eksternal.

\section{Trade-off Theory}

Menurut (Prasetiono, 2016) konsep cash holding dalam trade-off theory adalah membandingkan biaya marginal yang dikeluarkan dengan manfaat marginal yang diperoleh perusahaan dari memegang kas untuk memaksimalkan kekayaan pemegang saham dan nilai perusahaan. Perusahaan menetapkan tingkat kas yang optimal. Menurut (Saputri \& Kuswardono, 2019) menahan kas dapat menimbulkan biaya marginal yaitu hilangnya return investasi jangka pendek. Menurut (Margaretha \& Dewi, 2020) manfaat yang diperoleh dari menahan kas adalah 
berkurangnya peluang mengalami kesulitan kas, dapat melakukan investasi, dan menghemat biaya konversi.

\section{Cash Holding}

Menurut (Kurniawan \& Tanusdjaja, 2020) definisi dari cash holding adalah manajemen perusahaan atas kas dimana akan ditentukan seberapa banyak kas akan ditahan. Kas ini akan dipakai dalam melakukan investasi ataupun dibagikan sebagai dividen kepada para investor. Menurut (Liestyasih \& Wiagustini, 2017) cash holding digunakan untuk pembiayaan investasi, cadangan untuk kejadian yang tidak terduga, dibagikan sebagai dividen, serta menghindari terjadinya likuidasi aset. Jumlah kas yang ditahan mengindikasikan perusahaan dengan likuiditas yang baik. Perusahaan harus mempertimbangkan penyediaan kas dalam jumlah yang ideal.

\section{Pertumbuhan Penjualan}

Menurut (Liestyasih \& Wiagustini, 2017) tingginya kesempatan perusahaan bertumbuh merupakan sinyal yang baik bagi investor dimana sebagai tanda harapan memperoleh pengembalian investasi yang baik. (Silviana \& Asyik, 2016) menunjukkan bahwa kemampuan perusahaan memperoleh penjualan yang tinggi memiliki pertumbuhan penjualan yang tinggi. Perusahaan dengan peningkatan yang tinggi dalam penjualan cenderung lebih dapat menahan kas dimana kas tersebut akan digunakan untuk investasi di waktu yang akan datang.

Tingkat pertumbuhan perusahaan menentukan kelangsungan hidup perusahaan di masa yang akan datang.

\section{Leverage}

(Irwanto, Sia, Agustina, \& An, 2019) menjelaskan leverage adalah rasio untuk mengukur sejauhmana hutang dipakai untuk membiayai aset perusahaan. Semakin tinggi leverage semakin besar risiko yang dihadapi perusahaan. Penggunaan hutang yang tinggi diikuti dengan beban bunga yang tinggi. Jika manfaat penggunaan hutang lebih besar dari beban bunga yang timbul, hal ini akan meningkatkan cash holding.

\section{Ukuran Perusahaan}

Menurut (Kurniawan \& Tanusdjaja, 2020) ukuran perusahaan merupakan besar kecilnya suatu perusahaan yang antara lain dapat dilihat dari total aset perusahaan. Menurut (Irwanto, Sia, Agustina, \& An, 2019) ukuran perusahaan adalah skala yang mengklasifikasikan besar kecilnya perusahaan berdasarkan total aset, nilai pasar saham, nilai penjualan, dan lain-lain. Menurut (Simanjuntak \& Wahyudi, 2017) perusahaan dengan total aset besar mempunyai biaya kebangkrutan relative 
kecil, rendahnya biaya financial distress, dan mempunyai nilai jaminan lebih besar. Perusahaan dengan total aset besar memiliki kemudahan dalam memperoleh pendanaan eksternal karena nilai jaminan aset besar. Dalam pengambilan keputusan berinvestasi, investor memperhatikan ukuran perusahaan karena berkaitan dengan risiko dari suatu investasi.

\section{Profitabilitas}

(Saputri \& Kuswardono, 2019) menjelaskan rasio profitabilitas menilai kemampuan perusahaan dalam memperoleh keuntungan. Return on asset mengukur kemampuan perusahaan menghasilkan keuntungan dengan menggunakan aset yang dimiliki perusahaan. Menurut (Simanjuntak \& Wahyudi, 2017) profitabilitas merupakan hasil antara kebijakan dan keputusan yang diambil oleh perusahaan serta hubungan antara pendapatan dan biaya yang dihasilkan perusahaan dari penggunaan aset perusahaan dalam kegiatan produksi. Profitabilitas tinggi mencerminkan kemampuan perusahaan mengolah asetasetnya dengan maksimal. Potensial investor menganalisis kemampuan perusahaan dalam memperoleh keuntungan.

\section{Penelitian Terdahulu}

Penelitian (Liestyasih \& Wiagustini, 2017), Suherman (2017), (Ashhari \& Faizal, 2018), serta (Romadhoni,
Kufepaksi, \& Hendrawaty, 2019) menunjukkan bahwa pertumbuhan penjualan berdampak positif terhadap cash holding. Hasil penelitian ini bertolak belakang dengan penelitian (Alicia, Putra, Fortuna, Felin, \& Purba, 2020) dan (Astuti, Ristiyana, \& Nuraini, 2020) dimana pertumbuhan penjualan tidak berdampak positif terhadap cash holding. Juga tidak konsisten dengan penelitian (Simanjuntak \& Wahyudi, 2017), (Irwanto, Sia, Agustina, \& An, 2019), (Aristi, Khalida, \& Azmi, 2021), serta (Sari \& Zoraya, 2021) yang memperoleh hasil pertumbuhan penjualan tidak berdampak negatif terhadap cash holding. Selain itu penelitian (Gionia \& Susanti, 2020) memperoleh hasil pertumbuhan penjualan berdampak negatif terhadap cash holding. Penelitian (Ashhari \& Faizal, 2018), (Sethi \& Swain, 2019), (Zulyani \& Hardiyanto, 2019), (Alicia, Putra, Fortuna, Felin, \& Purba, 2020), (Gionia \& Susanti, 2020), serta (Chandra \& Dewi, 2021) memperoleh hasil leverage berdampak positif terhadap cash holding. Berbeda dengan hasil penelitian (Prasetiono, 2016), (Shabbir, Hashmi, \& Chaudhary, 2016), (Ahmed, Qi, Ullah, \& Kimani, 2018), (Agung \& Hadinugroho, 2019), (Irwanto, Sia, Agustina, \& An, 2019), (Saputri \& Kuswardono, 2019), (Yudaruddin, 2019), (Jason \& Viriany, 2020), (Sitorus, Simbolon, \& Hajanirina, 2020), dan (Aristi, Khalida, \& Azmi, 2021) dimana leverage berdampak negatif 
terhadap cash holding. Selain itu, penelitian (Simanjuntak \& Wahyudi, 2017), Suherman (2017), (Tayem, 2017), (Romadhoni, Kufepaksi, \& Hendrawaty, 2019), (Singh \& Misra, 2019), (Elnathan \& Susanto, 2020), serta (Kurniawan \& Tanusdjaja, 2020) memperoleh hasil leverage tidak berdampak negatif terhadap cash holding. Penelitian (Christina, Sugiarto, \& Indrajati, 2020), (Wiratama \& Ardiansyah, 2021), serta (Sari \& Zoraya, 2021)memperoleh hasil leverage tidak berdampak positif terhadap cash holding. (Prasetiono, 2016), (Shabbir, Hashmi, \& Chaudhary, 2016), (Irwanto, Sia, Agustina, \& An, 2019), (Saputri \& Kuswardono, 2019), (Romadhoni, Kufepaksi, \& Hendrawaty, 2019), (Alicia, Putra, Fortuna, Felin, \& Purba, 2020), (Elnathan \& Susanto, 2020), serta (Kurniawan \& Tanusdjaja, 2020) memperoleh hasil penelitian yaitu ukuran perusahaan berdampak positif terhadap cash holding. Tetapi bertolak belakang dengan penelitian (Yudaruddin, 2019), (Zulyani \& Hardiyanto, 2019), (Gionia \& Susanti, 2020), (Sitorus, Simbolon, \& Hajanirina, 2020), serta (Wiratama \& Ardiansyah, 2021) dimana ukuran perusahaan tidak berdampak positif terhadap cash holding. Penelitian (Liestyasih \& Wiagustini, 2017), Suherman (2017), (Ahmed, Qi, Ullah, \& Kimani, 2018), (Ashhari \& Faizal, 2018), (Agung \& Hadinugroho,
2019), (Sethi \& Swain, 2019), (Singh \& Misra, 2019), serta (Wijaya \& Bangun, 2019) memperoleh hasil ukuran perusahaan berdampak negatif terhadap cash holding. Penelitian (Simanjuntak \& Wahyudi, 2017), (Tayem, 2017), (Wijaya \& Bangun, 2019), (Astuti, Ristiyana, \& Nuraini, 2020), (Margaretha \& Dewi, 2020), (Chandra \& Dewi, 2021), serta (Sari \& Zoraya, 2021) memperoleh hasil ukuran perusahaan tidak berdampak negatif terhadap cash holding. Penelitian (Simanjuntak \& Wahyudi, 2017), (Agung \& Hadinugroho, 2019), (Irwanto, Sia, Agustina, \& An, 2019), (Sethi \& Swain, 2019), (Elnathan \& Susanto, 2020), (Christina, Sugiarto, \& Indrajati, 2020), (Kurniawan \& Tanusdjaja, 2020), serta (Margaretha \& Dewi, 2020) menunjukkan profitabilitas berdampak positif terhadap cash holding. Penelitian ini tidak konsisten dengan penelitian (Ridha, Wahyuni, \& Sari, 2019) serta (Chandra \& Dewi, 2021) yang memperoleh hasil profitabilitas tidak berdampak negatif terhadap cash holding. Selain itu (Romadhoni, Kufepaksi, \& Hendrawaty, 2019) serta (Jason \& Viriany, 2020) memperoleh hasil profitabilitas tidak berdampak positif terhadap cash holding.

\section{Pengembangan Hipotesis}

\section{Dampak Pertumbuhan Penjualan Terhadap Cash Holding}

Menurut (Gionia \& Susanti, 2020) 
perusahaan dengan peluang pertumbuhan yang tinggi cenderung menggunakan aset likuid untuk pendanaan investasi seperti membeli aset untuk ekspansi. Kas yang dikeluarkan lebih banyak sehingga kas yang tersedia lebih sedikit. Pertumbuhan penjualan tinggi maka kas yang tersedia lebih kecil. Perusahaan yang mampu mengeluarkan hutang baru akan mempunyai lebih sedikit kas yang ditahan karena kas digunakan untuk mendanai peluang investasi baru. Berdasarkan penjelasan di atas maka perumusan hipotesis yang dibentuk adalah:

$\mathrm{Ha}_{1}$ : Pertumbuhan penjualan berdampak negatif terhadap cash holding.

\section{Dampak Leverage Terhadap Cash Holding}

Menurut (Alicia, Putra, Fortuna, Felin, \& Purba, 2020) perusahaan dengan hutang besar, harus melakukan pembayaran pokok dan beban bunga secara periodik. Penundaan pembayaran kewajiban akan menimbulkan beban bunga yang lebih besar sehingga perusahaan harus menyediakan cadangan kas untuk melunasi kewajiban tersebut tepat waktu. Menurut (Ahmed, Qi, Ullah, \& Kimani, 2018) dari perspektif trade-off theory, perusahaan dengan leverage tinggi menghadapi risiko kesulitan keuangan yang lebih tinggi sehingga perusahaan harus memegang lebih banyak kas. Berdasarkan penjelasan di atas maka perumusan hipotesis yang dibentuk adalah:
$\mathrm{Ha}_{2}$ : Leverage berdampak positif terhadap cash holding.

\section{Dampak Ukuran Perusahaan Terhadap Cash Holding}

(Irwanto, Sia, Agustina, \& An, 2019) menjelaskan semakin besar ukuran suatu perusahaan artinya perusahaan tersebut mempunyai aset yang semakin besar pula, sehingga akan dapat menghasilkan kas karena besarnya aset yang dimiliki dapat digunakan untuk memperoleh laba. Hal ini sesuai dengan (Alicia, Putra, Fortuna, Felin, \& Purba, 2020) yang menjelaskan perusahaan dengan ukuran besar akan memiliki kemampuan yang lebih besar pula untuk menjaga cash holding-nya karena perusahaan ini dapat lebih menjaga tingkat investasi maupun operasinya bila dibandingkan dengan perusahaan yang lebih kecil. Perusahaan besar dianggap mampu menghasilkan kas dari kegiatan operasinya. Perusahaan akan menjaga ketersediaan kas yang dapat digunakan sebagai cadangan untuk kejadian yang tidak terduga. Hal ini mencerminkan kemampuan perusahaan untuk bertahan dalam menghadapi kesulitan. Berdasarkan penjelasan di atas maka perumusan hipotesis yang dibentuk adalah:

Ha3: Ukuran perusahaan berdampak positif terhadap cash holding.

Dampak Profitabilitas Terhadap Cash Holding.

Pecking order theory menjelaskan hubungan positif antara profitabilitas dan 
kas yang tersedia karena uang tunai merupakan hasil dari pembiayaan dan kegiatan investasi. Menurut (Saputri \& Kuswardono, 2019) terdapat hubungan yang berbanding lurus antara profitabilitas dengan kas yang tersedia. Perusahaan mengakumulasi lebih banyak kas yang tersedia untuk kebutuhan masa depan. Menurut (Irwanto, Sia, Agustina, \& An, 2019) meningkatnya produktivitas aset dalam memperoleh laba bersih mencerminkan kemampuan perusahaan meningkatkan kas yang tersedia. Menurut
(Christina, Sugiarto, \& Indrajati, 2020) profitabilitas tinggi menunjukkan perusahaan akan menggunakan keuntungan tersebut untuk meningkatkan likuiditas dengan mengakumulasikan keuntungan yang diperoleh ke dalam bentuk kas. Berdasarkan penjelasan di atas maka perumusan hipotesis yang dibentuk adalah:

$\mathrm{Ha}_{4}$ : Profitabilitas berdampak positif terhadap cash holding.

Model dalam penelitian ini berdasarkan penjelasan di atas adalah:

Gambar 1. Model Penelitian

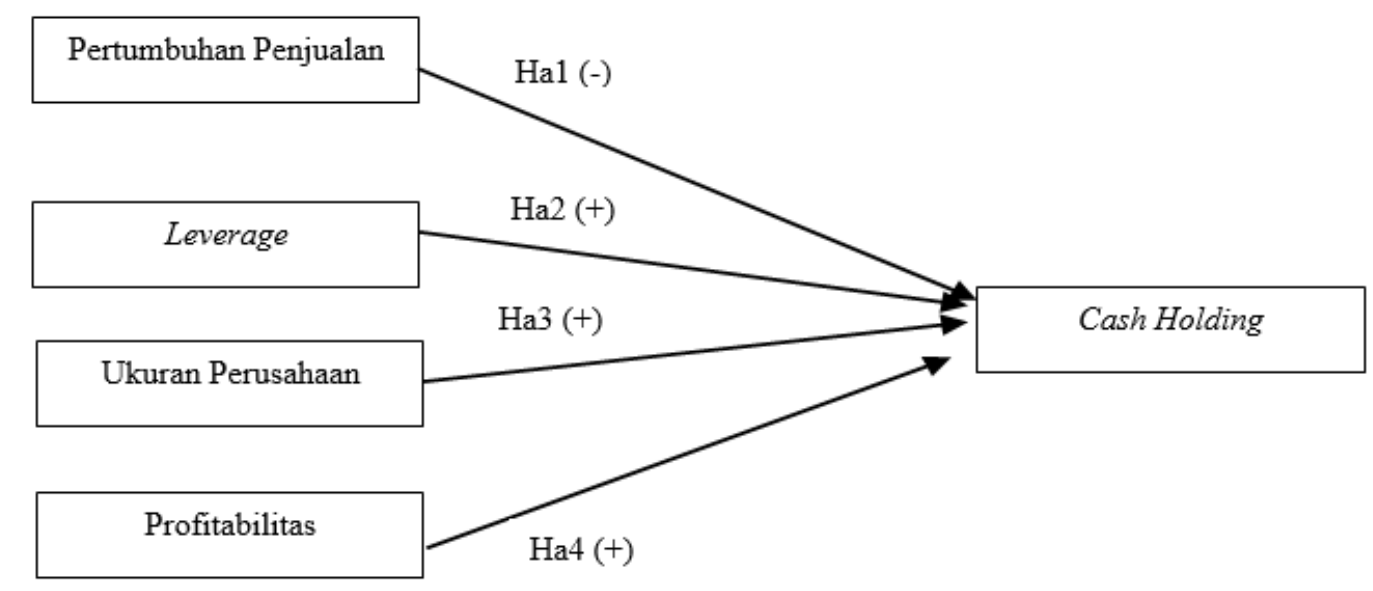

\section{METODOLOGI PENELITIAN}

\section{Populasi dan Sampel}

Populasi dalam penelitian ini adalah seluruh perusahaan manufaktur yang terdaftar secara konsisten di BEI selama periode 2016-2019. Pemilihan sampel menggunakan teknik purposive sampling. Kriteria sampel yaitu: (1) Perusahaan tidak mengalami kerugian, (2) Perusahaan menyajikan laporan keuangan dengan menggunakan mata uang Rupiah, (3) Perusahaan menyajikan laporan keuangan yang berakhir pada tanggal 31 Desember. Berdasarkan kriteria tersebut maka diperoleh sampel sebanyak 72 perusahaan dan dengan periode penelitian selama tiga 
tahun yaitu dari tahun 2017-2019 maka diperoleh 216 data.

Teknik Pengumpulan

Data Data dikumpulkan dari laporan keuangan masing-masing perusahaan manufaktur yang terdaftar secara konsisten di Bursa Efek Indonesia selama periode 2017-2019. Data yang sudah terkumpul ini kemudian diolah dengan mengggunakan EVIEWS.

$$
\mathrm{CH}-\frac{\text { Cash and Cash Equivalent }}{\text { Total Assets }}
$$

Sesuai penelitian (Alicia, Putra, Fortuna, penjualan yang diberi simbol SG diukur Felin, \& Purba, 2020) pertumbuhan dengan menggunakan rumus:

$$
\text { SG }=\frac{\text { Sales }_{t}-\text { Sales }_{t-1}}{\text { Sales }}
$$

Sesuai penelitian (Alicia, Putra, Fortuna, yang diberi simbol DAR diukur dengan Felin, \& Purba, 2020) leverage menggunakan rumus:

$$
\mathrm{DAR}=\frac{\text { Total Deht }}{\text { Total Asset }}
$$

Sesuai penelitian (Alicia, Putra, Fortuna, yang diberi simbol SIZE diukur dengan Felin, \& Purba, 2020) ukuran perusahaan menggunakan rumus:

\section{SIZE = Ln Total Asset}

Sesuai penelitian (Margaretha \& Dewi, ROA diukurdengan menggunakan rumus:

2020) profitabilitas yang diberi simbol

\section{HASIL DAN PEMBAHASAN}

$$
\mathrm{ROA}=\frac{\text { Net income }}{\text { Total Assots }}
$$

\section{Statistik Deskriptif}

Statistik deskriptif untuk masing-masing dapat dilihat di bawah (Tabel 1). variabel 
Tabel 1. Statistik Deskriptif

\begin{tabular}{lcccc}
\hline & Minimum & Maksimum & Mean & Standard Deviation \\
\hline CH & 0,000864 & 0,723993 & 0,117537 & 0,130156 \\
SG & $-0,889891$ & 0,858872 & 0,077658 & 0,190611 \\
DAR & 0,066532 & 0,844782 & 0,391078 & 0,185844 \\
SIZE & 25,79571 & 33,49453 & 28,71111 & 1,563497 \\
ROA & 0,000282 & 0,920997 & 0,085358 & 0,108600 \\
\hline
\end{tabular}

Cash holding $(\mathrm{CH})$ mempunyai nilai minimum sebesar 0,000864 , nilai maksimum sebesar 0,723993, dan nilai mean sebesar 0,117537 dengan standar deviasi sebesar 0,130156. Hal ini berarti cash holding memiliki data yang bervariasi. Pertumbuhan penjualan (SG) mempunyai nilai minimum sebesar 0,889891, nilai maksimum sebesar 0,858872, dan nilai mean sebesar 0,077658 dengan standar deviasi sebesar 0,190611. Hal ini berarti pertumbuhan penjualan memiliki data yang bervariasi. Leverage (DAR) mempunyai nilai minimum sebesar 0,066532, nilai maksimum sebesar 0,844782 , dan nilai mean sebesar 0,391078 dengan standar

\section{Uji Common Effect Model}

Hasil uji common effect model dapat deviasi sebesar 0,185844 . Hal ini berarti leverage memiliki data yang tidak bervariasi. Ukuran perusahaan (SIZE) mempunyai nilai minimum sebesar 25,79571, nilai maksimum sebesar 33,49453, dan nilai mean sebesar 28,71111 dengan standar deviasi sebesar 1,563497. Hal ini berarti ukuran perusahaan memiliki data yang tidak bervariasi. Profitabilitas (ROA) mempunyai nilai minimum sebesar 0,000282, nilai maksimum sebesar 0,920997, dan nilai mean sebesar 0,085358 dengan standar deviasi sebesar 0,108600 . Hal ini berarti profitabilitas memiliki data yang bervariasi.

Tabel 2. Hasil Uji Common Effect Model

\begin{tabular}{ccccc}
\hline Variable & Coefficient & Std.Error & t-Statistic & Prob. \\
\hline C & 0,249545 & 0,148806 & 1,676980 & 0,0950 \\
SG & 0,023189 & 0,043064 & 0,538492 & 0,5908 \\
DAR & $-0,275876$ & 0,044491 & $-6,200675$ & 0,0000 \\
SIZE & $-0,001547$ & 0,005287 & $-0,292610$ & 0,7701 \\
ROA & 0,216735 & 0,075968 & 2,852956 & 0,0048 \\
\hline
\end{tabular}




\section{Uji Fixed Effect Model}

Hasil uji fixed effect model dapat dilihat di bawah (Tabel 3).

Tabel 3. Hasil Uji Fixed Effect Model

\begin{tabular}{ccccc}
\hline Variable & Coefficient & Std.Error & t-Statistic & Prob. \\
\hline C & $-1,021457$ & 0,841253 & $-1,214209$ & 0,2267 \\
SG & $-0,076974$ & 0,021803 & $-3,530368$ & 0,0006 \\
SAR & 0,097439 & 0,101689 & 0,958211 & 0,3396 \\
ROA & 0,038456 & 0,029660 & 1,296566 & 0,1969 \\
\hline
\end{tabular}

\section{Uji Chow}

Hasil uji Chow dapat dilihat di bawah

(Tabel 4).

Tabel 4. Hasil Uji Chow

\begin{tabular}{cccc}
\hline Effects Tes & Statistic & d.f. & Prob. \\
\hline Cross-section F & 15,839803 & $(71,140)$ & 0,0000 \\
Cross-section Chi-square & 475,392089 & 71 & 0,0000 \\
\hline
\end{tabular}

Hasil uji Chow menunjukkan nilai probabilitas F sebesar 0,0000 atau lebih kecil dari 0,05 sehingga model yang dipilih adalah fixed effect model.
Uji Random Effect Model. Hasil uji random effect model dapat dilihat di bawah (Tabel 5).

Tabel 5. Hasil Uji Random Effect Model

\begin{tabular}{ccccc}
\hline Variable & Coefficient & Std.Error & t-Statistic & Prob. \\
\hline C & 0,139168 & 0,230659 & 0,603350 & 0,5469 \\
SG & $-0,066928$ & 0,021423 & $-3,124046$ & 0,0020 \\
DAR & $-0,145798$ & 0,058052 & $-2,511500$ & 0,0128 \\
SIZE & 0,001099 & 0,008139 & 0,135081 & 0,8927 \\
ROA & 0,105665 & 0,053378 & 1,979547 & 0,0491 \\
\hline
\end{tabular}

\section{Uji Hausman}

Hasil uji Hausman dapat dilihat di bawah

(Tabel 6)

Tabel 6. Hasil Uji Hausman

\begin{tabular}{cccc}
\hline Test Summary & Chi-Sq & & \\
& Statistic & Chi-Sq. d. f. & Prob \\
\hline Cross-section random & 20,179744 & 4 & 0,0005 \\
\hline
\end{tabular}

Hasil uji Hausman menunjukkan nilai probabilitas sebesar 0,0005 atau lebih kecil dari 0,05 sehingga model yang dipilih adalah fixed effect model.

\section{Adjusted $\boldsymbol{R}$-squared}

Hasil uji Adjusted R-squared dapat Dilihat 
di bawah (Tabel 7)

Tabel 7. Hasil Uji Adjusted R-squared

\begin{tabular}{ccc}
\hline Variabel & Adjusted $R$-squared & Keterangan \\
\hline $\mathrm{CH}$ & 0,863288 & Kuat \\
\hline
\end{tabular}

Berdasarkan tabel 7. diperoleh nilai Adjusted R-squared sebesar 0,863288. Hal ini berarti pengaruh pertumbuhan penjualan (SG), leverage (DAR), ukuran perusahaan (SIZE), dan profitabilitas (ROA) terhadap cash holding $(\mathrm{CH})$ kuat karena sebanyak 86,3288\% cash holding dalam penelitian ini dapat dijelaskan

Tabel 8. Hasil Uji Hipotesis pertumbuhan penjualan (SG), leverage (DAR), ukuran perusahaan (SIZE), dan profitabilitas (ROA) sedangkan sisanya $13,6712 \%$ dijelaskan oleh variabel lain di luar model penelitian.

Hasil Uji Hipotesis. Hasil uji hipotesis dapat dilihat di bawah (Tabel 8).

\begin{tabular}{lccc}
\hline & Coefficient & p-value & Keterangan \\
\hline $\mathrm{SG} \rightarrow \mathrm{CH}$ & $-0,076974$ & 0,0006 & $\mathrm{Ha}_{1}$ diterima \\
$\mathrm{DAR} \rightarrow \mathrm{CH}$ & 0,097439 & 0,3396 & $\mathrm{Ha}_{2}$ tidak diterima \\
$\mathrm{SIZE} \rightarrow \mathrm{CH}$ & 0,038456 & 0,1969 & $\mathrm{Ha}_{3}$ tidak diterima \\
$\mathrm{ROA} \rightarrow \mathrm{CH}$ & 0,032194 & 0,5886 & $\mathrm{Ha}_{4}$ tidak diterima \\
\hline
\end{tabular}

Koefisien regresi pertumbuhan penjualan (SG) terhadap cash holding $(\mathrm{CH})$ adalah negatif sebesar -0,076974. Jika dilihat dari $p$-value, nilai $p$-value sebesar 0,0006 dimana nilai ini $<$ dari 0,05 . Ini berarti $\mathrm{Ha} 1$ diterima dan pertumbuhan penjualan (SG) berdampak negatif terhadap cash holding $(\mathrm{CH})$. Koefisien regresi leverage (DAR) terhadap cash holding $(\mathrm{CH})$ adalah positif sebesar 0,097439. Jika dilihat dari p-value, nilai $p$-value sebesar 0,3396 dimana nilai ini $>$ dari 0,05 . Ini berarti $\mathrm{Ha} 2$ tidak diterima dan leverage (DAR) tidak berdampak positif terhadap cash holding $(\mathrm{CH})$. Koefisien regresi ukuran perusahaan (SIZE) terhadap cash holding $(\mathrm{CH})$ adalah positifsebesar 0,038456. Jika dilihat dari $p$ value, nilai $p$-value sebesar 0,1969 dimana nilai ini $>$ dari 0,05 . Ini berarti Ha3 tidak diterima dan ukuran perusahaan (SIZE) tidak berdampak positif terhadap cash holding $(\mathrm{CH})$. Koefisien regresi profitabilitas (ROA) terhadap cash holding (CH) adalah positif sebesar 0,032194. Jika dilihat dari $p$-value, nilai $p$-value sebesar 0,5886 dimana nilai ini $>$ dari 0,05 . Ini

berarti Ha4 tidak diterima dan profitabilitas (ROA) tidak berdampak positif terhadap cash holding $(\mathrm{CH})$.

\section{Pembahasan.}

Pertumbuhan penjualan berdampak negatif terhadap cash holding. Hasil penelitian ini 
Jurnal Bina Akuntansi, Januari 2022, Vol.9, No.1, Hal. 74 - 93

konsisten dengan penelitian (Gionia \& Susanti, 2020) yang memperoleh hasil pertumbuhan penjualan berdampak negatif terhadap cash holding. Hasil penelitian ini tidak konsisten dengan penelitian (Liestyasih \& Wiagustini, 2017), Suherman (2017), (Ashhari \& Faizal, 2018), serta (Romadhoni, Kufepaksi, \& Hendrawaty, 2019) yang menyatakan bahwa pertumbuhan penjualan berdampak positif terhadap cash holding. Hasil penelitian ini tidak konsisten dengan penelitian (Alicia, Putra, Fortuna, Felin, \& Purba, 2020) dan (Astuti, Ristiyana, \& Nuraini, 2020) dimana hasil penelitian menunjukkan pertumbuhan penjualan tidak berdampak positif terhadap cash holding. Penelitian ini juga tidak konsisten dengan penelitian (Simanjuntak \& Wahyudi, 2017), (Irwanto, Sia, Agustina, \& An, 2019), (Aristi, Khalida, \& Azmi, 2021), serta (Sari \& Zoraya, 2021) yang memperoleh hasil pertumbuhan penjualan tidak berdampak negatif terhadap cash holding. Perusahaan yang mengalami pertumbuhan penjualan akan melakukan ekspansi dengan membeli aset tetap yang lebih banyak sehingga perusahaan cenderung melakukan investasi aset tetap dibandingkan menahan kas untuk kegiatan operasional. Akibatnya kas yang digunakan lebih banyak sehingga kas yang tersedia lebih sedikit. Perusahaan yang mampu mengeluarkan hutang baru akan mempunyai lebih sedikit kas yang ditahan karena kas digunakan untuk mendanai peluang investasi baru. Penjualan yang besar memerlukan biaya yang lebih besar untuk memenuhi kebutuhan operasional perusahaan. Hampir sebagian besar perusahaan manufaktur melakukan penjualan secara kredit. Pertumbuhan penjualan tidak meningkatkan kas yang diperoleh saat itu tetapi menaikkan aset perusahaan dalam bentuk piutang sehingga kas yang tersedia tidak banyak. Leverage tidak berdampak positif terhadap cash holding. Hasil ini konsisten dengan penelitian (Christina, Sugiarto, \& Indrajati, 2020), (Wiratama \& Ardiansyah, 2021), serta (Sari \& Zoraya, 2021) yang memperoleh hasil leverage tidak berdampak positif terhadap cash holding. Hasil penelitian ini tidak konsisten dengan penelitian yang dilakukan (Ashhari \& Faizal, 2018), (Sethi \& Swain, 2019), (Zulyani \& Hardiyanto, 2019), (Alicia, Putra, Fortuna, Felin, \& Purba, 2020), (Gionia \& Susanti, 2020), serta (Chandra \& Dewi, 2021) yang memperoleh hasil leverage berdampak positif terhadap cash holding. Selain itu, hasil penelitian ini juga tidak konsisten dengan (Simanjuntak \& Wahyudi, 2017), Suherman (2017), (Tayem, 2017), (Romadhoni, Kufepaksi, \& Hendrawaty, 2019), (Singh \& Misra, 2019), (Elnathan \& Susanto, 2020), serta (Kurniawan \& Tanusdjaja, 2020) yang memperoleh hasil leverage tidak berdampak negatif terhadap cash holding. 
Berbeda juga dengan penelitian (Prasetiono, 2016), (Shabbir, Hashmi, \& Chaudhary, 2016), (Ahmed, Qi, Ullah, \& Kimani, 2018), (Agung \& Hadinugroho, 2019), (Irwanto, Sia, Agustina, \& An, 2019), (Saputri \& Kuswardono, 2019), (Yudaruddin, 2019), (Jason \& Viriany, 2020), (Sitorus, Simbolon, \& Hajanirina, 2020), dan (Aristi, Khalida, \& Azmi, 2021)yang menunjukkan leverage berdampak negatif terhadap cash holding. Perusahaan yang memiliki leverage yang besar mencerminkan penggunaan dana eksternal yang besar dalam operasi perusahaan. Leverage besar menimbulkan kewajiban pembayaran pokok dan beban bunga secara periodik. Perusahaan harus menyediakan kas untuk melunasi kewajiban tersebut pada saat jatuh tempo. Penundaan pembayaran kewajiban akan menimbulkan beban bunga yang lebih besar. Leverage besar berdampak pada jumlah kas yang ditahan lebih besar supaya perusahaan tidak mengalami kesulitan dalam melakukan pelunasan kewajiban. Hasil penelitian ini menunjukkan leverage tidak berdampak positif pada cash holding. Leverage yang tinggi tidak meningkatkan kas yang tersedia di perusahaan. Leverage tinggi mencerminkan perusahaan memiliki kemudahaan untuk mendapatkan pendanaan eksternal. Kas yang diperoleh dari pendanaan eksternal digunakan untuk ekspansi perusahaan dengan membeli aset tetap untuk meningkatkan produktivitas perusahaan. Penambahan aset tetap yang produktif akan meningkatkan penjualan perusahaan. Peningkatan penjualan akan meningkatkan laba yang diperoleh sehingga beban bunga yang timbul dari hutang lebih kecil dari peningkatan keuntungan perusahaan. Perusahaan memiliki pandangan kas yang tersedia dalam jumlah banyak akan menurunkan kinerja perusahan karena tidak memberikan return yang maksimal. Hal inilah yang mendorong perusahaan dengan leverage tinggi cenderung tidak menahan kas dalam jumlah banyak. Ukuran perusahaan tidak berdampak positif terhadap cash holding. Hasil ini konsisten dengan penelitian (Yudaruddin, 2019), (Zulyani \& Hardiyanto, 2019), (Gionia \& Susanti, 2020), (Sitorus, Simbolon, \& Hajanirina, 2020), serta (Wiratama \& Ardiansyah, 2021) yang menjelaskan ukuran perusahaan tidak berdampak positif terhadap cash holding. Hasil penelitian ini tidak konsisten dengan (Prasetiono, 2016), (Shabbir, Hashmi, \& Chaudhary, 2016), (Irwanto, Sia, Agustina, \& An, 2019), (Saputri \& Kuswardono, 2019), (Romadhoni, Kufepaksi, \& Hendrawaty, 2019), (Alicia, Putra, Fortuna, Felin, \& Purba, 2020), (Elnathan \& Susanto, 2020), serta (Kurniawan \& Tanusdjaja, 2020) yang menjelaskan ukuran perusahaan 
Jurnal Bina Akuntansi, Januari 2022, Vol.9, No.1, Hal. 74 - 93

berdampak positif terhadap cash holding.

Hasil penelitian ini juga tidak konsisten dengan (Liestyasih \& Wiagustini, 2017), Suherman (2017), (Ahmed, Qi, Ullah, \& Kimani, 2018), (Ashhari \& Faizal, 2018), (Agung \& Hadinugroho, 2019), (Sethi \& Swain, 2019), (Singh \& Misra, 2019), serta (Wijaya \& Bangun, 2019) yang menjelaskan ukuran perusahaan berdampak negatif terhadap cash holding. Juga tidak konsisten dengan penelitian (Simanjuntak \& Wahyudi, 2017), (Tayem, 2017), (Wijaya \& Bangun, 2019), (Astuti, Ristiyana, \& Nuraini, 2020), (Margaretha \& Dewi, 2020), (Chandra \& Dewi, 2021), serta (Sari \& Zoraya, 2021) yang memperoleh hasil ukuran perusahaan tidak berdampak negatif terhadap cash holding. Ukuran perusahaan besar artinya perusahaan mempunyai aset dan tingkat penjualan yang besar untuk memperoleh laba. Perusahaan besar dianggap mampu menghasilkan kas lebih banyak dibandingkan perusahan kecil. Perusahaan besar akan menjaga ketersediaan kas yang lebih banyak dibanding perusahaan kecil untuk membiayai kegiatan operasional dan sebagai cadangan untuk kejadian yang tidak terduga. Hasil penelitian ini menunjukkan ukuran perusahaan tidak berdampak positif pada cash holding. Meskipun perusahaan menghasilkan kas dalam jumlah besar tetapi perusahaan tidak menahan kas dalam jumlah banyak. Perusahaan besar cenderung memiliki kemudahan memperoleh pendanaan eksternal dikarenakan aset yang besar dapat digunakan sebagai jaminan. Perusahaan besar dalam berinvestasi untuk meningkatkan kinerja perusahaan cenderung memilih menggunakan pendanaan eksternal dibanding pendanaan internal. Hal ini mendorong perusahaan untuk menahan sedikit kas. Selain itu kas yang dihasilkan dari operasi perusahaan digunakan untuk berinvestasi dalam bentuk surat berharga jangka pendek yang mudah diperjualbelikan untuk menghasilkan return dari kenaikan harga surat berharga tersebut, sehingga kas yang tersedia optimal dimana cukup untuk kegiatan operasi perusahaan. Jika perusahaan memerlukan kas secara mendesak, perusahaan dapat segera menjual surat berharganya. Profitabilitas tidak berdampak positif terhadap cash holding. Hasil penelitian ini konsisten dengan (Romadhoni, Kufepaksi, \& Hendrawaty, 2019) serta (Jason \& Viriany, 2020) yang menyatakan profitabilitas tidak berdampak positif terhadap cash holding. Hasil penelitian ini tidak konsisten dengan (Simanjuntak \& Wahyudi, 2017), (Agung \& Hadinugroho, 2019), (Irwanto, Sia, Agustina, \& An, 2019), (Sethi \& Swain, 2019), (Elnathan \& Susanto, 2020), (Christina, Sugiarto, \& Indrajati, 2020), (Kurniawan \& Tanusdjaja, 2020), serta (Margaretha \& Dewi, 2020) yang menunjukkan profitabilitas berdampak 
positif terhadap cash holding. Selain itu, hasil penelitian ini juga tidak konsisten dengan (Ridha, Wahyuni, \& Sari, 2019) serta (Chandra \& Dewi, 2021) yang memperoleh hasil profitabilitas tidak berdampak negatif terhadap cash holding. Bertambahnya produktivitas aset akan meningkatkan penjualan yang akhirnya akan meningkatkan laba yang dihasilkan. Kemampuan perusahaan meningkatkan laba yang diperoleh mencerminkan kemampuan perusahaan meningkatkan kas yang tersedia. Perusahaan mengakumulasi lebih banyak kas yang tersedia untuk kebutuhan masa depan. Perusahaan SIMPULAN

Tujuan penelitian ini untuk memperoleh bukti empiris mengenai dampak negatif pertumbuhan penjualan terhadap cash holding, dampak positif leverage terhadap cash holding, dampak positif ukuran perusahaan terhadap cash holding, dan dampak positif profitabilitas terhadap cash holding. Hasil penelitian yang dilakukan menunjukkan bahwa pertumbuhan penjualan berdampak negatif terhadap cash holding, leverage tidak berdampak positif terhadap cash holding, ukuran perusahaan tidak berdampak positif terhadap cash holding, dan profitabilitas tidak berdampak positif terhadap cash holding. Implikasi penelitian ini adalah membantu manajemen perusahaan untuk dengan profitabilitas tinggi memiliki akses mudah untuk memperoleh pendanaan eksternal dengan biaya lebih rendah dan dianggap memiliki kemampuan untuk membayar hutang dari kas yang tersedia. Ternyata profitabilitas yang tinggi tidak berdampak pada kas yang tersedia. Peningkatan penjualan akan meningkatkan laba. Keuntungan yang diperoleh digunakan oleh perusahaan untuk mengembangkan usaha dengan menambah aset produksi. Selain itu perusahaan memperoleh laba dan akan membagikan dividen kas kepada pemegang saham sehingga kas yang tersedia sedikit.

mengambil keputusan menentukan kas tersedia yang optimal. Keterbatasan penelitian ini adalah sampel penelitian hanya perusahaan manufaktur sehingga hasil penelitian ini tidak dapat digeneralisasi untuk semua sektor perusahaan. Data penelitian hanya mencakup tiga tahun dimana periode penelitian 2017-2019. Jumlah variabel independen hanya empat variabel. Penelitian selanjutnya dapat memperluas sektor industri sebagai populasi, menambah periode penelitian, dan menambah variabel independen lain yang diduga memengaruhi cash holding seperti likuiditas, net working capital, dan cash flow. 


\section{DAFTAR PUSTAKA}

Agung, S. W., \& Hadinugroho, B. (2019). Analisis Firms Size, Profitabilitas, dan Leverage Terhadap Cash Holding Pada Perusahaan Manufaktur Yang Terdaftar di BEI Tahun 2016-2018. Prosiding Seminar Nasional dan Call for Papers, Fakultas Ekonomi Universitas Tidar, 15 Oktober 2019, 20-35. Prosiding Seminar Nasional dan Call for Papers, Fakultas Ekonomi Universitas Tidar (pp. 20-35). Magelang: Fakultas Ekonomi Universitas Tidar.

Ahmed, R., Qi, W., Ullah, S., \& Kimani, D. (2018). Determinants of Corporate Cash Holdings: An Empirical Study of Chinese Listed Firms. Corporate Ownership \& Control, Vol. 15, No. 3, 57-65.

Alicia, R., Putra, J., Fortuna, W., Felin, F., \& Purba, M. I. (2020). Pengaruh Growth Opportunity, Leverage, dan Firm Size Terhadap Cash Holding Perusahaan Properti dan Real Estate. Owner: Riset dan Jurnal Akuntansi, Vol. 4, No. 2, 322-329.

Aristi, M. D., Khalida, M., \& Azmi, Z. (2021). Faktor-Faktor Yang Mempengaruhi Cash Holding Pada Perusahaan Sektor Industri Barang Konsumsi. Jurnal Akuntansi \& Ekonomika, Vol. 11, No. 1, 23-32.
Ashhari, Z. M., \& Faizal, D. R. (2018). Determinants And Performance of Cash Holding: Evidence from Small Business in Malaysia. International Journal of Economics, Management and Accounting, Vol. 26, No. 2, 457473.

Astuti, N., Ristiyana, R., \& Nuraini, L. (2020). Faktor-Faktor Yang Mempengaruhi Cash Holding. Jurnal Ekonomi Bisnis, Vol. 26, No. 1, 243-252.

Chandra, \& Dewi, S. P. (2021). FaktorFaktor Yang Memengaruhi Cash Holding Pada Perusahaan Manufaktur. . Jurnal Multiparadigma Akuntansi, Vol. 3, No. 2, 550-558.

Christina, C., Sugiarto, E., \& Indrajati, M. F. (2020). Faktor-Faktor Yang Mempengaruhi Cash Holding Pada Perusahaan Manufaktur Tahun 2016-2018. Jurnal Multiparadigma Akuntansi Tarumanagara, Vol. 2, No. 3, 1096-1103.

Elnathan, Z., \& Susanto, L. (2020). Pengaruh Leverage, Firm Size, Likuiditas, dan Profitabilitas Terhadap Cash Holding. urnal Multiparadigma Akuntansi, Vol. 2, No. 1, 40-49.

Gionia, \& Susanti, M. (2020). FaktorFaktor Yang Mempengaruhi Cash 
Holding Pada Perusahaan

Manufaktur di Indonesia. Jurnal

Multiparadigma

Akuntansi

Tarumanagara, Vol. 2, No. 2, 1026-1035.

Irwanto, Sia, S., Agustina, \& An, E. J. (2019). Faktor Yang Mempengaruhi Cash Holding dan Nilai Perusahaan Manufaktur. Jurnal Wira Ekonomi Mikroskil, Vol. 9, No. 2, 147-158.

Jason, E., \& Viriany. (2020). Analisis Faktor-Faktor Yang Mempengaruhi Cash Holding Pada Perusahaan Manufaktur di Indonesia. Jurnal Multiparadigma Akuntansi Tarumanagara, Vol. 2, No. 4, 1415-1424.

Kurniawan, H., \& Tanusdjaja, H. (2020). Pengaruh Leverage, Firm Size, Profitability, dan Liquidity Terhadap Corporate Cash Holding. Jurnal Multiparadigma Akuntansi Tarumanagara, Vol. 2, No. 3, 954961.

Liestyasih, L. P., \& Wiagustini, L. P. (2017). Pengaruh Firm Size dan Growth Opportunity Terhadap Cash Holding dan Firm Value. EJurnal Ekonomi dan Bisnis Universitas Udayana, Vol. 6, No. 10, 3607-3636.

Margaretha, I., \& Dewi, S. P. (2020). Faktor-Faktor Yang Mempengaruhi
Cash Holding Pada Perusahaan Manufaktur. Jurnal Multiparadigma Akuntansi, Vol. 2, No. 1, 1-9.

Myers, S. C., \& Majluf, N. S. (1984). Corporate Financing and Investment Decisions When Firms Have Information That Investors Do Not Have. Journal of Financial Economics, Vol. 13, No. 2, 187221.

Prasetiono, A. S. (2016). Analisis FaktorFaktor yang Mempengaruhi Kebijakan Cash Holding Pada Perusahaan Manufaktur Yang Listing di Bursa Efek Indonesia Tahun 2010-2014. Diponegoro Journal of Management, Vol. 5, No. 4, 1-11.

Ridha, A., Wahyuni, D., \& Sari, D. M. (2019). Analisis Pengaruh Kepemilikan Institusional dan Profitabilitas Terhadap Cash Holding Dengan Ukuran Perusahaan Sebagai Variabel Moderasi Pada Perusahaan Terindeks LQ45 di Bursa Efek Indonesia. Jurnal Manajemen dan Keuangan, Vol. 8, No. 2, 135-150.

Romadhoni, R., Kufepaksi, M., \& Hendrawaty, E. (2019). FaktorFaktor Yang Mempengaruhi Cash Holding Perusahaan Yang Listing di Bursa Efek Indonesia Tahun 
2013-2017. The Manager Review,

Vol. 1, No. 2, 124-139.

Saputri, E., \& Kuswardono, A. (2019).

Pengaruh Profitabilitas, Leverage,

Firm Size, dan Growth Opportunity

Terhadap Cash Holding Perusahaan

(Studi Kasus Perusahaan

Manufaktur Yang Terdaftar Pada

Bursa Efek Indonesia Periode

Tahun 2013-2017). Journal of

Entrepreneurship, Management, and Industry, Vol. 2, No. 2, 91-104.

Sari, M., \& Zoraya, I. (2021). Analisis

Faktor-Faktor Yang Memengaruhi

Cash Holding Pada Perusahaan

Industri Sektor Barang Konsumsi

Yang Terdaftar di Bursa Efek

Indonesia Tahun 2009-2018.

Management Insight: Jurnal Ilmiah

Manajemen, 16(1), 61-80.

Management Insight: Jurnal Ilmiah

Manajemen, Vol. 16, No. 1, 61-80.

Sethi, M., \& Swain, R. (2019).

Determinant of Cash Holdings: A

Study of Manufacturing Firms in

India. International Journal of

Management Studies, Vol. 2, No. 2, 11-26.

Shabbir, M., Hashmi, S. H., \& Chaudhary, G. M. (2016). Determinants of Corporate Cash Holdings in Pakistan. International Journal of Organizational Leadership, Vol. 5, No. 1, 50-62.

Silviana, R., \& Asyik, N. F. (2016).
Pengaruh Pertumbuhan Penjualan, Profitabilitas, dan Kebijakan Dividen Terhadap Perubahan Laba. Jurnal Ilmu dan Riset Akuntansi, Vol. 5, No. 1, 1- 21.

Simanjuntak, S. F., \& Wahyudi, A. S. (2017). Faktor-Faktor yang Mempengaruhi Cash Holding Perusahaan. Jurnal Bisnis dan Akuntansi, Vol. 19, No. 1a, 25-31.

Singh, K., \& Misra, M. (2019). Financial Determinants of Cash Holding Levels: An Analysis of Indian Agricultural Enterprises. Agricultural Economics-Czech, Vol. 65, No. 5, 240-248.

Sitorus, M. I., Simbolon, I. P., \& Hajanirina, A. (2020). The Determinants of Corporate Cash Holding in Indonesia: Manufacturing Company. Journal of Applied Accounting and Finance, Vol. 4, No. 2, 120-130.

Tayem, G. (2017). The Determinants of Corporate Cash Holdings: The Case of a Small Emerging Market. International Journal of Financial Research, Vol. 8, No. 1, 143-154.

Wijaya, S. H., \& Bangun, N. (2019). Pengaruh Arus Kas, Leverage, dan Ukuran Perusahaan Terhadap Cash Holding. Jurnal Paradigma Akuntansi, Vol. 1, No. 2, 495-504.

Wiratama, E., \& Ardiansyah. (2021). Faktor-Faktor Yang Mempengaruhi 
Dampak Pertumbuhan Penjualan, Leverage, Ukuran Perusahaan,dan Profitabilitas Terhadap Cash Holding

Cash Holding Perusahaan

Manufaktur Yang Terdaftar di BEI.

Jurnal Multiparadigma Akuntansi,

Vol. 3, No. 2, 775-783.

Yudaruddin, R. (2019). Determinants of Corporate Cash Holdings:

Evidence of The Mining Sector in Indonesia. International Journal of Scientific \& Technology Research, Vol. 8, No. 10, 1523-1526.

Zulyani, \& Hardiyanto. (2019). Faktorfaktor yang Mempengaruhi Cash Holdings Pada Perusahaan Pelayaran di Indonesia. Jurnal Inovasi Bisnis, Vol. 7, 8-14. 